\title{
Students' Quantitative Literacy in Solving PISA Problem Based on Gender Differences
}

\author{
Lestariningsih $^{1 *}$, Nita Safitri Maulidah ${ }^{1}$, Moch. Lutfianto ${ }^{2}$ \\ ${ }^{1}$ Program Studi Pendidikan Matematika, STKIP PGRI Sidoarjo \\ ${ }^{2}$ Program Studi Pendidikan Matematika, STKIP Al Hikmah Surabaya \\ *lestari.med@gmail.com
}

\begin{abstract}
Quantitative literacy is an important skill needed by individuals in solving problems with quantitative situations in daily life. Thus, this paper aimed to identify quantitative literacy in solving the PISA problem based on gender differences. This study used descriptive research with a qualitative approach. Research subjects in this study were two tenth-grade students in middle school. They were one male student and one female student who have the similar mathematical ability. Data were collected by giving the Program for International Student Assessment (PISA) problem, especially mathematical literacy, and using the interview method. The research results showed that the quantitative literacy of male student in solving PISA problems is by using fewless symbols to represent time and incomplete algorithms and procedures. In comparison, the quantitative literacy of female student in solving PISA problems is by using a more detailed description, more mathematical operations, and solving the problem according to algorithms and procedures. Furthermore, both students have quantitative literacy aspects, including interpretation, calculation, representation, assumption, analysis, and communication skills. Therefore, the quantitative literacy ability of students can be used as a reference for teachers to determine the modeling activities conducted by students in solving the PISA problem.
\end{abstract}

Keywords: female student, male student, PISA problem, quantitative literacy

Received: May 28, 2021 / Accepted: June 29, 2021 / Published Online: July 16, 2021

\section{Introduction}

The rapid development of information and technology requires people to use quantitative literacy in their daily lives. Quantitative literacy is increasingly essential for informed citizenship or a variety of careers (Lindner, 2012). According to Steen (2001), the challenges of the 21 st century are more quantitative, and all information is related to mathematical numbers. The importance of quantitative literacy was that quantitative literacy continues to develop in a world that is increasingly quantitative and data-intensive (Frith \& Prince, 2018; Hains, Intindola, Lepisto, \& Wagner, 2019; Nye \& Hillyard, 2013). Therefore, the education sector must prepare students to have quantitative literacy skills through the learning process in schools. Students are expected to interpret mathematical information relevant to existing 
problems, represent data from tables or graphs, calculate data, analyze, and communicate mathematical ideas.

Quantitative literacy is one of the dimensions of mathematical literacy, apart from spatial literacy and numerical literacy (Anggara, Kadir, \& Haribowo, 2021). In addition, Lange (2006) states that mathematical literacy consists of numerical, spatial, and quantitative literacy. Quantitative literacy is a person's ability to reason and think mathematically in quantitative content (Steen, 2001). On the other hand, mathematical literacy is an individual's capacity to formulate, employ and interpret mathematics in various contexts (OECD, 2019a).

The Organization for Economic Cooperation Development (OECD) conducted a study related to mathematical literacy skills, namely the Program for International Student Assessments (PISA) (Annizar, Maulyda, Khairunnisa, \& Hijriani, 2020; Frith \& Prince, 2018). This assessment used the PISA problem, which is designed based on aspects of mathematical content and context. The context indicates the places or locations that exist in the problem, and mathematical content is a mathematical topic used in problems (Lestariningsih, Amin, Lukito, \& Lutfianto, 2018). Indonesia participates in every survey conducted by PISA. Based on the results of PISA research in 2018 issued by the OECD (OECD, 2019a), the math score of Indonesian students is ranked 72 out of 78 countries with an average score of 379. In the 2018 PISA assessment, it was found that around $28 \%$ of students in Indonesia reached level 2 (OECD, 2019b). It implies that Indonesia has low mathematical literacy. Based on this assessment, because quantitative literacy is one of the dimensions of mathematical literacy, it means that the quantitative literacy of Indonesian students is still relatively low.

Boersma and Klyve (2013) suggested that quantitative literacy is a habit of thinking characterized by understanding everyday problems about mathematics, beliefs, and dispositions towards mathematics. Furthermore, quantitative literacy is used much more broadly to include logic, linguistics, and other subjects that have at least a relatively formal character even if they are seldom or ever taught in mathematics departments (Frith \& Prince, 2018; Karaali, VillafaneHernandez, \& Taylor, 2016; Klug, Carey, Richardson, \& Gougis, 2017). Quantitative literacy relates to quantities (Srimuliati, 2018; Vacher, 2014; Wallace, 2019). Quantitative literacy is a skill, knowledge, belief, disposition, habit of thinking, communication capability, and problemsolving skills that require people to engage effectively in quantitative situations that arise in life and work. The application of his knowledge is in the context of everyday life to complete quantitative problems in work and life. Roohr, Graf, \& Liu (2014) stated six aspects in assessing quantitative literacy, namely interpretation, representation, calculation, analysis, assumptions, 
and communication. These six aspects will be indicators of quantitative literacy in this study.

According to Bench, Lench, Liew, Miner, and Flores (2015), men have better mathematical skills in accuracy, thoroughness, accuracy, and thinking than do women. The results of Azizi’s research Azizi (2017) stated that female mathematical literacy skills were better than male students in context, content, and process. Gender differences can lead to differences in quantitative literacy skills between men and women in solving PISA problems. However, there has been no research on students' quantitative literacy in solving PISA problems so far. The existing research is about students' quantitative literacy based on gender.

Regarding the previous explanations, i.e., Azizi (2017); Frith \& Prince (2018); Hains et al. (2019); Karaali et al. (2016); Nye \& Hillyard (2013); Roohr et al. (2014); and Vacher (2014) researchers are interested in research on students' quantitative literacy in solving PISA problems based on gender. Thus, this paper aimed at identifying male and female quantitative literacy in solving PISA problems.

\section{Method}

This study was designed using descriptive research with a qualitative approach. Qualitative research is not to generalize the findings but to analyze the subject's condition in depth. Furthermore, qualitative research does not require a certain number of research subjects to take. Research subjects in this study were two tenth-grade students middle-aged 15 years. They were one male student and one female student who have the similar mathematical ability. Subjects in this study were taken based on gender differences. Gender difference is identified from a person's physical condition brought from birth and psychological conditions influenced by habits or the environment. Their selection was based on the recommendations from a mathematics teacher by considering their scores in mathematics.

Data collection to identify students' quantitative literacy was conducted by asking research subjects to complete the PISA problem. Table 1 showed the PISA problem with quantity content and personal context. Before the PISA problem was used, the validity was performed through expert reviews to maintain the quality of the problem. After completing the PISA problem, we interviewed them to get more information about students' quantitative literacy. In this study, to check the validity of the data, we used triangulation by comparing the students' answers and the script of an interview. Data analysis from the results of interviews in this study were using qualitative analysis that consists of three stages, namely condensation data, presentation data, and concludes by referring to the opinions (Miles, M. B., Huberman, A. M., \& Saldaña, 2019). 


\section{Problem:}

Helen gets a new bicycle. The bike has a speedometer on the handlebars. The speedometer can tell Helen about the distance covered and the average speed for the trip. Helen rides a bicycle to her house for $6 \mathrm{~km}$. The speedometer showed that the average speed was 18 $\mathrm{km}$ per hour for the entire trip. Helen left the house at 10.00, how many minutes Helen arrived at her house?

The data analysis technique used was the analysis of the data from students' answers to the quantitative literacy problem and the analysis of the interview, based on six aspects of quantitative literacy consisting of interpretation, representation, calculation, analysis, assumption, and communication. The aspects and indicators of quantitative literacy used in this study refer to Table 1.

Table 1. The aspects and indicators of quantitative literacy

\begin{tabular}{|c|c|}
\hline Aspects & Indicators \\
\hline Interpretation & $\begin{array}{l}\text { Student can collect relevant mathematical information in a } \\
\text { mathematical problem }\end{array}$ \\
\hline Representation & $\begin{array}{l}\text { Student can transform the relevant information into various } \\
\text { forms of mathematics (mathematical models) }\end{array}$ \\
\hline Calculation & Student can operate any relevant information in mathematics \\
\hline Analysis & $\begin{array}{l}\text { Student can draw conclusions based on the analysis of the data } \\
\text { that has been collected }\end{array}$ \\
\hline Assumption & $\begin{array}{l}\text { Student can make important assumptions in estimating, } \\
\text { modelling, and analyzing data }\end{array}$ \\
\hline Communication & $\begin{array}{l}\text { Student can explain mathematical ideas through written, oral, } \\
\text { and demonstrate and describe visually }\end{array}$ \\
\hline
\end{tabular}

Through data analysis of students' answers in solving PISA problems and interview analysis, it can be seen how students' quantitative literacy through all or several aspects of the six aspects of quantitative literacy.

\section{Results}

\section{Male student quantitative literacy in solving PISA problem}

Quantitative literacy analysis of male subject on the abilities of interpretation, representation, calculation, assumptions, analysis, and communication in solving PISA problem could be known from the following explanation.

\begin{tabular}{|l|c|}
\hline Diket: & Translation: \\
$S: 6 \mathrm{~km}$ & Given: \\
$\mathrm{S}=6 \mathrm{~km}$ \\
$\mathrm{~V}=18 \mathrm{~km} / \mathrm{Jam}$ & $\mathrm{V}=18 \mathrm{~km} / \mathrm{jam}$ \\
$\mathrm{t}=10.08$ \\
Dita: menit helen ke rumah bibi?
\end{tabular}

Figure 1. Male answer (1) 
1. Quantitative literacy in interpretation ability

Figure 1 shows that male student could write down aspects that are known and asked in the problem. Male student could explain relevant mathematical information from the existing problem. The following was the conversation between the researcher $(\mathrm{R})$ and male student $(\mathrm{M})$ when an interview was conducted.

$\mathrm{R}:$ What do you know from the problem?

M: What I know is the distance is 6, the mean speed is 18 kilometers per hour and departure time at 10:00.

$\mathrm{R}:$ What was asked from the question?

M: Minutes Helen to get to her house.

Based on the results of male student's answers in solving PISA problem and interviews, it can be said that male student can determine relevant mathematical information in a problem but not detail when he was in the interpretation aspect.

2. Quantitative literacy in representation ability

In Figure 1, it can be seen that male student wrote symbols to estimate the distance with $\mathrm{s}$, the velocity with $\mathrm{v}$, and the length of time it takes with t. However, the male student wrote that 10:00 is t. The male student could transform and explain relevant information into various forms of mathematics. Based on the results of male student's answers in solving PISA problems and interviews, it showed that male student could make mathematical models according to relevant information in the representation aspect.

3. Quantitative literacy in calculation ability

In Figure 2, it can be seen that male student used the division and multiplication count operations and carried out the calculation process correctly. The male student also explained the calculation process used in solving the problem appropriately. Student could also complete the problem given by researchers.

$t=\frac{s}{V}=\frac{6}{18}=\frac{1}{3} \times 6 \sigma^{20}=20$ menit
Jadi waktu yang ditempun helen 20 menit
$\quad \begin{aligned} & \text { Translation: } \\ & t=\frac{s}{v}=\frac{6}{18}=\frac{1}{3} \times 60=20 \text { minutes } \\ & \text { So, Helen takes } 20 \text { minutes }\end{aligned}$

Figure 2. Male answer (2) 
4. Quantitative literacy in analytical ability

In Figure 2, it can be seen that male student made conclusions from the process of solving the problem based on existing information. The male student explained the process of solving the problem from the relevant information collected to conclude the existing problem. Student could determine the related information needed to complete a problem.

5. Quantitative literacy in assumption ability

In Figure 2, it can be seen that male student wrote down the assumptions used to complete the problem, namely the time formula is proportional to distance and inversely proportional to speed. Male student could also describe the ideas of existing problems using a mathematical form. The following was the conversation between the researcher $(\mathrm{R})$ and male student (M) when we conducted the interviewed.

$\mathrm{R}$ : What was the first time you thought about solving this problem?

M: Find the time using the formula $\overline{t=\frac{s}{v}}$

$\mathrm{R}$ : Did you find a different way to complete the problem? Explain! M: No.

Based on the results of male student's answers in solving PISA problem and interviews, it showed that he can describe the explanation of their thought patterns well.

6. Quantitative literacy in communication ability

Figure 2 shows that male student wrote down problems by completing steps based on the information that had been collected. Male subject also explains mathematical ideas through verbal by demonstrating, and visualizing them. The following was the conversation between the researcher $(\mathrm{R})$ and male student $(\mathrm{M})$ when we conducted the interviewed.

$\mathrm{R}:$ What are the steps you took in solving the problems? Explain!

M: First, write down what you know in advance, such as distance, speed, andwhat time she leaves. After that, enter the formula $t^{t=\frac{s}{v}}$ immediately. If you are looking for time using $t=\frac{s}{v}$, then immediately enter $s$ it as 6 kilometers, then $v$ is 16 kilometers per hour. Divided by $\sqrt{\frac{6}{18}=\frac{1}{3}}$ immediately, then $\sqrt{\frac{6}{18}=\frac{1}{3}}$ minutes

$\mathrm{R}$ : Why is it multiplied by 60 minutes?

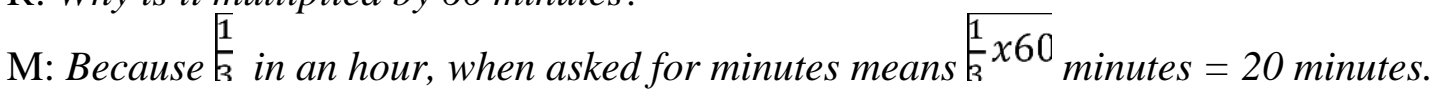

Based on the results of male student's answers in solving PISA problem and interviews, it shows that student can explain the steps used in solving problem-based on relevant information. 


\section{Female student's quantitative literacy in solving PISA problem}

Quantitative literacy analysis of female student on their ability to interpret, to represent, to calculate, to assume, to analyze, and to communicate on PISA problem could be known from the following explanation.

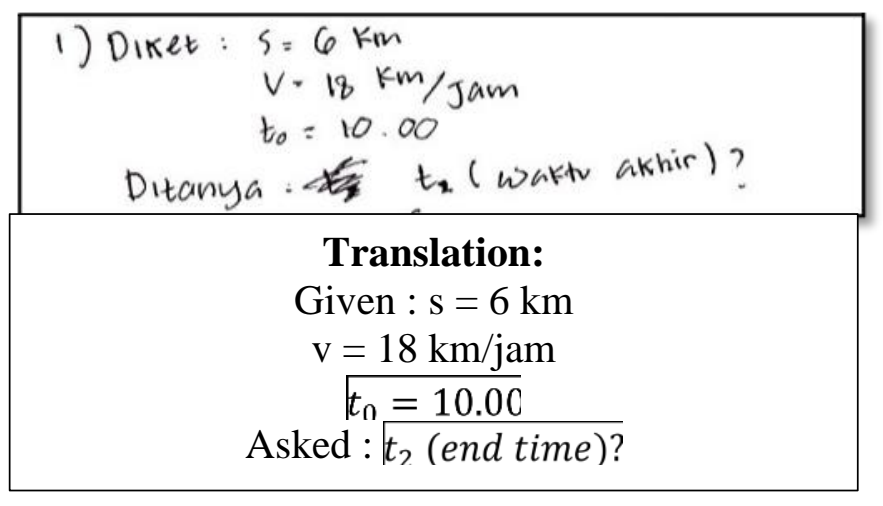

Figure 3. Female answer (1)

1. Quantitative literacy in interpretation ability

In Figure 3, it can be seen that the female student wrote what they knew and was asked in the questions correctly. The female student also expressed what was known and asked the questions correctly. The following was the conversation between the researcher (R) and female student $(F)$ when interviewed.

$\mathrm{R}$ : What do you know from the questions?

F: So, we know the distance $(d)$ is 6 kilometers, then the mean of speed is 18

kilometres per hour, it is known that the initial time is ten.

$\mathrm{R}$ : What was asked from the question?

F: You were asked how many minutes Helen arrived at her house.

Based on the results of female student's answers in solving PISA problem and interviews, it showed that the interpretation of female subject is carried out by determining relevant mathematical information on a problem in detail and accurately.

2. Quantitative literacy in representation ability

In Figure 3, it can be seen that female student used symbols to assume the distance with $\mathrm{s}$, the average velocity with $\mathrm{v}$, the time taken with $\mathrm{t}$, the time to depart with $\mathrm{t}_{1}$, and the time up to $t_{2}$. The female student revealed that she transformed the relevant information into various forms of mathematics. The following was the conversation between the researcher $(\mathrm{R})$ and female student $(\mathrm{F})$ when we conducted the interview.

R: Did you write down what you know, what you ask using mathematics sentences?

F: Yes

$\mathrm{R}:$ Could you explain!

$\mathrm{F}$ : If the distance is $s$, if the speed is $v$, if the initial time is $t_{1}$ 
Based on the results of female student's answers in solving PISA problem and interviews, it showed that female student makes mathematical models according to relevant information (Figure 3).

3. Quantitative literacy in calculation ability

In Figure 4, it can be seen that the female student correctly used the multiplication, addition, and division arithmetic operations. Female student also revealed the calculation process in solving PISA problem based on existing information. It shows that the female student could answer questions given by researchers.

4. Quantitative literacy in analytical ability

In Figure 4, it can be seen that female student made conclusions from the process of solving the problem based on existing information. Female student also revealed the process of solving the problem based on existing information, and drawing conclusions from the problem. Based on the results of female student's answers in solving PISA problem and interviews, it showed that female student can determine the related information needed to complete a problem.

5. Quantitative literacy in assumption ability

In Figure 4, it can be seen that female student wrote down the assumptions used to complete the existing problem. Female student also expressed the assumptions made in solving the problem. The following was the conversation between the researcher $(\mathrm{R})$ and female student $(\mathrm{F})$ when we conducted the interviewed.

$\mathrm{R}:$ What was the first time you thought about solving this problem?

$\mathrm{F}$ : Using the formula $t=\frac{s}{v}$ because you find the time and you know that distance equals velocity

R: Did you find a different way to complete the problem? Explain!

F: Nothing.

Based on the results of female student's answers in solving PISA problem and interviews, it shows that female student can describe the explanation of their thought patterns well. 


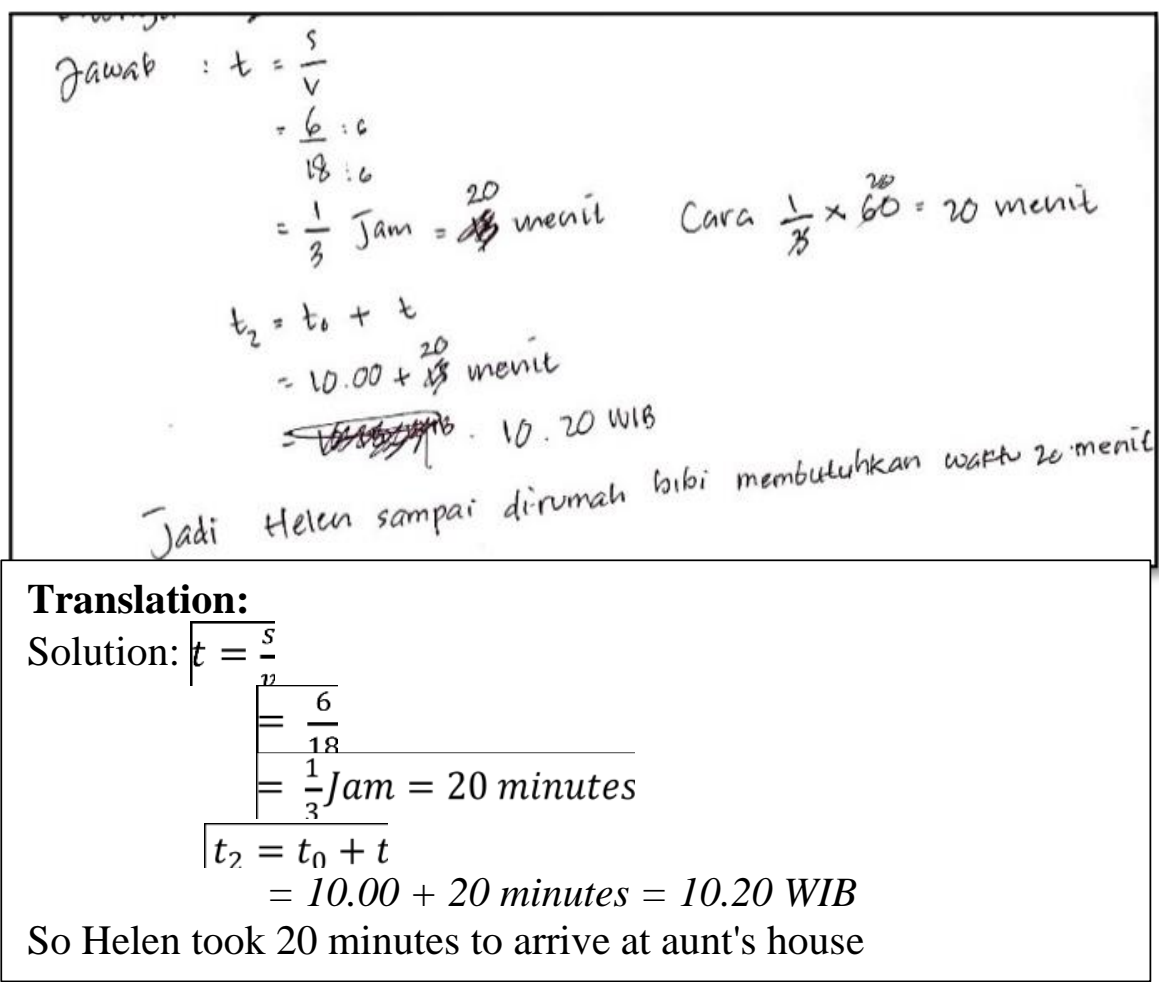

Figure 4. Female answer (2)

6. Quantitative literacy in ability

Figure 4 showed that female student wrote down the problem solving the process of problem. Female student also explained mathematical ideas through oral, demonstrate, and describe visually. She said, "First, we look for it from a distance of 6 kilometres, then an average speed of 18 kilometres per hour, secondly $t_{1}$, the initial time is ten. Then asked $t_{2}$, the final time is the distance divided by the speed, the distance is 6 kilometres, then the average speed is 18 kilometres per hour, divided if 6 divided by 6 is 1,18 divided by 6 is 3 , so the result is then $\frac{\sqrt{1}}{3}$ multiplied by 60 to become minutes, right? 1 hour $=60$ minutes, make $\sqrt{\frac{1}{3} \times 60}$ so the result is 20 minutes. “

According to the student's answer in solving quantitative literacy problems and interviews, it showed that female student can explain the steps used in solving the problem based on relevant information.

\section{Discussion}

Based on the data obtained from student's answers in solving quantitative literacy problems and interviews, it was found that female and male students had the same aspects of 
quantitative literacy. Its aspects included interpretation ability, representation ability, calculation ability, assumption ability, analytical ability, and communication ability.

For male student, the interpretation aspect was carried out by using incomplete verbal descriptions, giving rise to ambiguous meanings, the representation aspect was carried out by using one symbol to express time (Karaali et al., 2016), the calculation aspect was carried out by operating and explaining each calculation used in solving problem appropriately. Then the analytical aspect was carried out by making and explaining conclusions based on the analysis of the data that had been collected. The assumption aspect was carried out by making important assumptions in estimating, modeling, and analyzing data. Last, the communication aspect of male student was carried out by explaining mathematical ideas through writing, speaking, and demonstrating and describing them visually.

However, the female student was carried out the interpretation aspect by stating what is known and what is asked in the problem appropriately. It is in line with the research results by (Lestariningsih, Nurhayati, \& Lutfianto, 2020). The representation aspect of a female student was carried out by using variations to express the symbols of the beginning and the end answer. Then the calculation aspect was carried out by operating and by explaining each calculation that completes the problem appropriately (Fatmawati, 2019). In addition, the analytical aspect of a female student was carried out by making and explaining conclusions based on the analysis of the data collected, and the assumption aspect was carried out by making important assumptions in estimating, modeling, and analyzing data. Last, the communication aspect of a female student was carried out by explaining mathematical ideas through writing, oral, demonstrating, and describing them visually.

So, it can be concluded that the quantitative literacy of male and female students is not different significantly. This analysis follows the results of research by Karmila (2018) and Reilly (2012), which showed that male quantitative literacy abilities are equivalent to female mathematical literacy abilities.

Furthermore, based on the answers, it is known that a female student used a more varied and more detailed representation than a male student in solving the problem. Both male and female students use representations in the form of symbols to express time, distance, and speed. It is in line with the research results conducted by Lestariningsih, Nurhayati, Susilo, Cicinidia, \& Lutfianto (2020) that students complete mathematics problems using representations in the form of symbols. 


\section{Conclusions}

Both male and female students have all aspects of quantitative literacy. In solving the PISA problem, they could collect relevant mathematical information in a mathematical problem. They could transform the relevant information into various mathematical models and operated any relevant information in mathematics. They could draw conclusions based on the analysis of data collected, and they made important essential assumptions in data estimation, modeling, and analysis. They could also explain mathematical ideas through writing and speaking, demonstrating and describing them visually.

The contribution of this research for teachers is that the differences in steps taken by male and female students in the aspect of interpretation need to be a concern for them in choosing an approach in teaching male student in class when they experience interpretation problems in mathematics lessons. Finally, we suggest further research to use PISA problems with different mathematical content or context in tracing students' quantitative literacy.

\section{References}

Anggara, D. S., Kadir, \& Haribowo, H. (2021). Content validity analysis on mathematical quantitative literacy instruments in elementary schools. Journal of Physics: Conference Series, 1918(4), 042091. https://doi.org/10.1088/1742-6596/1918/4/042091.

Annizar, M., Maulyda, A., Khairunnisa, F., \& Hijriani, L. (2020). Kemampuan pemecahan masalah matematis siswa dalam menyelesaikan soal PISA pada topik geometri. Jurnal Elemen, 6(1), 39-55. https://doi.org/10.29408/jel.v6i1.1688.

Azizi, R. (2017). Literasi matematika tingkat sekolah menengah pertama mengacu pada PISA (Programme for International Student Assessment) ditinjau dari gender. In Universitas Nusantara PGRI Kediri (Vol. 13). Kediri: Universitas Nusantara PGRI Kediri.

Bench, S. W., Lench, H. C., Liew, J., Miner, K., \& Flores, S. A. (2015). Gender gaps in overestimation of math performance. Sex Roles, 72(11-12), 536-546. https://doi.org/10.1007/s11199-015-0486-9.

Boersma, S., \& Klyve, D. (2013). Measuring habits of mind: Toward a prompt-less instrument for assessing quantitative literacy. Numeracy, 6(1), 1-14. https://doi.org/10.5038/19364660.6.1.6.

Fatmawati, A. (2019). Kemampuan literasi kuantitatif siswa kelas X ditinjau dari gaya kognitif. Prosiding Seminar Nasional Pendidikan Matematika, Universitas Muhammadiyah Malang.

Frith, V., \& Prince, R. (2018). The National benchmark quantitative literacy test for applicants to South African higher education. Numeracy, 11(2), 1-25. https://doi.org/10.5038/19364660.11.2.3.

Hains, D., Intindola, M., Lepisto, D., \& Wagner, B. (2019). Scrimmage! Teaching quantitative literacy through a multidimensional simulation. International Journal of Management Education, 17(1), 119-129. https://doi.org/10.1016/j.ijme.2019.01.002.

Karaali, G., Villafane-Hernandez, E., \& Taylor, J. (2016). What's in a name? A critical review of definitions of quantitative literacy, numeracy, and quantitative reasoning. Numeracy, 9(1), 1-34. https://doi.org/10.5038/1936-4660.9.1.2. 
Karmila. (2018). Deskripsi kemampuan literasi matematis siswa ditinjau dari gender. Pedagogy, 3(1), 126-137.

Klug, J. L., Carey, C. C., Richardson, D. C., \& Gougis, R. D. (2017). Analysis of highfrequency and long-term data in undergraduate ecology classes improves quantitative literacy. Ecosphere, 8(3), 1-13. https://doi.org/10.1002/ecs2.1733.

Lange, J. de. (2006). Mathematical literacy for living from OECD-PISA. Tsukuba Journal of Educational Study in Mathematics, 25(September), 13-35.

Lestariningsih, L., Amin, S. ., Lukito, A., \& Lutfianto, M. (2018). Mathematisation of preservice teacher in solving higher order thinking problem. 160 (Incomed 2017), 291294. https://doi.org/10.2991/incomed-17.2018.62.

Lestariningsih, L., Nurhayati, E., Susilo, T. A. B., Cicinidia, C., \& Lutfianto, M. (2020). Development of mathematical literacy problems to empower students' representation. Journal of Physics: Conference Series, 1464(1), 012018. https://doi.org/10.1088/17426596/1464/1/012018.

Lestariningsih, Nurhayati, E., \& Lutfianto, M. (2020). Students' thinking process in solving mathematical literacy problem with space and shape content. Journal of Physics: Conference Series, 1470(1), 012039. https://doi.org/10.1088/1742-6596/1470/1/012039.

Lindner, A. M. (2012). Teaching quantitative literacy through a regression analysis of exam $\begin{array}{llll}\text { performance. } & \text { Teaching } & \text { Sociology, } & 40(1),\end{array}$ https://doi.org/10.1177/0092055X11430401.

Miles, M. B., Huberman, A. M., \& Saldaña, J. (2019). Qualitative data analysis. In Qualitative Data Analysis: A Methods Sourcebook. https://doi.org/10.4324/9781315701134-11.

Nye, P., \& Hillyard, C. (2013). Personal financial behavior: The influence of quantitative literacy and material values. Numeracy, 6(1), 1-24. https://doi.org/10.5038/19364660.6.1.3.

OECD. (2019a). PISA 2018 assessment and analytical framework. In OECD Publishing. https://doi.org/10.1787/b25efab8-en.

OECD. (2019b). PISA 2018 results combined executive summaries. In PISA 2009 at a Glance. https://doi.org/10.1787/g222d18af-en.

Reilly, D. (2012). Gender, culture, and sex-typed cognitive abilities. PloS One, 7(7), 22808072. https://doi.org/10.1371/journal.pone.0039904.

Roohr, K. C., Graf, E. A., \& Liu, O. L. (2014). Assessing quantitative literacy in higher education: An overview of existing research and assessments with recommendations for next-generation assessment. ETS Research Report Series, 2014(2), 1-26. https://doi.org/10.1002/ets2.12024.

Srimuliati, S. (2018). Profil literasi kuantitatif mahasiswa matematika FTIK IAIN Langsa. AtTafkir, 11(1), 100-116. https://doi.org/10.32505/at.v11i1.530.

Steen, A. (2001). Mathematics and democracy: The case for quantitative literacy. Princeton, NJ: National Council on Education and the Disciplines and Woodrow Wilson Foundation.

Vacher, H. L. (2014). Looking at the multiple meanings of numeracy, quantitative literacy, and quantitative reasoning. Numeracy, 7(2), 1-14. https://doi.org/10.5038/1936-4660.7.2.1.

Wallace, D. (2019). Three formative questions in the quantitative literacy movement. Numeracy, 12(1), 1-8. https://doi.org/10.5038/1936-4660.12.1.13. 